\title{
Assessment of Hunters and Other Rate of Illegal Activities in Afi-Mbe-Okwango Division, Cross River State, Nigeria
}

\author{
Sodienye Augustine Abere', Funmilayo Lewiska Lateef ${ }^{2}$, Gbolagade Akeem Lameed ${ }^{2}$ \\ ${ }^{1}$ Department of Forestry and Environment, Faculty of Agriculture, River State University of Science and \\ Technology, Port Harcourt, Nigeria \\ ${ }^{2}$ Department of Wildlife and Ecotourism Management, Faculty of Agriculture and Forestry, University of Ibadan, \\ Ibadan, Nigeria \\ Email: lamgbola2008@gmail.com
}

Received 20 December 2015; accepted 28 May 2016; published 31 May 2016

Copyright (C) 2016 by authors and Scientific Research Publishing Inc.

This work is licensed under the Creative Commons Attribution International License (CC BY). http://creativecommons.org/licenses/by/4.0/

(c) (i) Open Access

\section{Abstract}

Bushmeat hunting is one of the greatest pressure to wildlife alongside habitat fragmentation, deforestation, land use change and climate change. Despite the interventions from government and Non Governmental Organization to reduce or divert the attention of rural people from the wild by providing alternative livelihood, the level of hunting either remains the same or kept on increasing. However, there is need to categorize and understand the types of hunters in different locality for better design and management of whatever alternative to be provided. The study assessed hunters' types and their income made from hunting in Afi, Mbe and the Okwango Division of the National park and the rate of poaching activities. The snowball sampling was adopted for gathering data. A descriptive and inferential statistical tool was used to analyze the data collected. The respondents were interviewed with a view to obtaining information on the regularity of their hunting activities, the income made per month and reasons why they hunt and also their views on best alternative. Results revealed that majority of the respondent fall within the age of less than or equal to 40 years with primary and secondary school qualification in which are married with 3 12 children. Consequent to this fact hunting activities is effective and prevailing. It further revealed that despite numerous conservation efforts in these areas, poaching activities still prevail owing to the fact that the income made from poaching is much better than the alternative provided for hunters. Furthermore, the assessment also revealed that there are different types of hunters and this makes their income varies greatly. Thus, there are fulltime or core hunters (36.9\%), occasional hunters (58.3\%), Holiday hunters $(2.9 \%)$ and social hunters $(1.9 \%)$. It is therefore paramount to have a better view and understanding of the target group (Poachers) for better alternative and implementation. 


\section{Keywords}

\section{Hunters, Income, Poaching, Afi-Mbe-Okwango Division}

\section{Introduction}

Bushmeat has been used by African communities for centuries [1] [2]. Today it is the primary source of animal protein as well as an important source of income for rural forest dwellers [3]. It is also a stated fact that many depend on wildlife as a buffer through times of adversity, or to gain additional resources for particular needs like school fees [1]. This "safety net" is paramount for vulnerable community members [4]. Wild meat income can also be differentially vital when crops fail. It tends to be relied on more by migrant labourers who have less time for livestock husbandry [5] and the protein from forest wildlife is crucial to rural food security and livelihoods across the tropics coupled with the income made from hunting. The harvest of animals such as tapir, duikers, deer, pigs, peccaries, primates and larger rodents, birds and reptiles provides benefits to local people worth millions of US Dollar annually and represents around 6 million tones of animals extracted yearly [6].

In respect to this fact, hunting of bushmeat (or wild meat) has been recognized as one of the largest threats to tropical forest biodiversity worldwide [7]-[10] and a number of different conservation strategies as prescribed by conservation practitioners, Policy maker, conservation lobbyists have been employed with the aim of reducing the bushmeat trade [11]. However, the effort of such strategy is yet to present ample evidence of project outcome or success as the case may be.

Afi-Mbe-Okwango forest in Cross River State is known to house the endangered Cross River Gorilla (Gorilla gorilla diehli) and Chimpanzee (Pan troglodytes ellioti) amongst other important species in the face of increasing rate of hunting irrespective of the numerous efforts of different NGOs and GOs to curb this menace. It is recently documented in the WCS action plan of 2011, that human population has grown steadily in both Cameroun and Nigeria, and that this has led to the ease of access to arms, more efficient transports systems, and higher financial incentives for supplying urban markets with bushmeat and other forest commodities leading to a "bushmeat crisis". Hunting of chimpanzees to supply the bushmeat trade and, to lesser extent, to provide traditional medicines is almost certainly the greatest threat to the survival of Pan troglodytes ellioti populations. In a five weeks period in 2009, a Wildlife Conservation Society survey of eight markets in the transboundry region of Cross River state, Nigeria found six Chimpanzee carcasses. Given the slow reproductive rate of chimpanzees, and the limited number of chimpanzees persisting in the wild in many areas, this hunting pressure cannot be sustained [12]. Also, according to WCS revised regional action plan [13], Poaching of three Cross River Gorrilas at Afi was recorded between 2011 and 2012 even though poaching activities was thought to have declined. The reduction of poaching activity is however not certain since poor people in rural areas of developing countries are often highly dependent on biodiversity to meet their day-to-day livelihood needs [14].

The provision of alternative protein and income-generating sources is one of the most widely used strategies at the community level to reduce bushmeat consumption and trade while aiming to improve (or have no negative impact on) local livelihoods [15]. While many such alternative livelihood projects have been implemented across West and Central Africa at various scales, there has been little or no assessment of illegal hunters as this is needful so has to inculcate this knowledge when planning and implementing alternative livelihood project that are focusing on hunters. There is therefore the need to categorize and understand the types of hunters, reason for hunting and income made from hunting in different locality for better design and management of whatever alternative to be provided.

\section{Study Area}

The Afi-Mbe-Okwangwo landscape is located in the Boki Local Government Area of Cross River State, Nigeria. It lies between latitudes $06^{\circ} 10^{\prime} \mathrm{N}$ and $06^{\circ} 30^{\prime} \mathrm{N}$, and longitudes $08^{\circ} 50^{\prime} \mathrm{E}$ and $09^{\circ} 30^{\prime} \mathrm{E}$ and covers an area of approximately 180,531 ha. Afi Mountain Wildlife Sanctuary is surrounded by 16 communities with a total population of approximately 27,000. It is managed by the Cross River State Forestry Commission with support from Wildlife Conservation Society and other partners such as the North Carolina Zoo and Pandrillus [16]. The Mbe Mountains is owned traditionally by the nine communities that surround it with a total of 10,000 people [16]. 
The Okwangwo division of the Cross River National Park (CRNP) is surrounded by at least 39 communities with a total population of some 29,000 [16].

\section{Materials and Method}

This study was conducted within the Afi-Mbe-Okwango axis (Figure 1). A total of 35 villages were purposely selected because of the various alternative livelihood project and conservation education by various NGOs and GOs that has been ongoing in the villages: At Mbe, all the nine communities (9) were adopted which include Abo Mkpang, Abo Obisu, Abo Ogbagante, Bokalum, Kayang 1, Kayang 2, Wula 1, Wula 2, and Bamba. At Afi, thirteen (13) communities were covered and these include Kachie, Enyi, Ebranta, Ebbakken, Kakwagom, Kakubok, Okubuchi, Esekwe, Bitiah, Nkanya, Asuben, and Ndemechang. And lastly, at the Okwangwo Division of the National Park, fourteen (14) communities were evaluated and this include Butatong, Busi 5, Anape, Kundeve II, Kakwe beebo, Baggabo, Bakie, Ogwefor, Yangwabe, Otsakwei, Buabre, Okwa I, Okwa II, and Okwangwo.

A total of 103 Hunters were reached through the snowball sampling [18] techniques with the aim of getting information regarding the number of times they hunt in a week, the income made from hunting per month, the types of hunters, hunting activities and the reason for hunting. Secondary information on poaching activities was collected from WCS Website and Head office in Calabar. The study was carried out within the space of two month. This was done through the help of village head which made it easy to identify hunters. Interviews were done orally with a tape recorded and later transcribed into transcripts. Descriptive statistics was used to analyze the data using Statistical Package such as SPSS and Microsoft Excel: frequencies, percentage analysis and one away analysis of variance method (ANOVA) were employed in order to investigate the significant difference in the mean income of the types of hunter.

\section{Results}

From Table 1, 93.2\% of the respondents interviewed are married while $6.8 \%$ are single. The study also revealed that $39.8 \% .52 .4 \%$ and $2.9 \%$ attended primary, secondary and tertiary institution respectively. The study further revealed that majorities (57.3\%) of the hunters in this axis are equal to or less than 40 years old. $36.9 \%$ falls between 41 and 60 years old and lastly, 5.8\% are 60 years old or less.

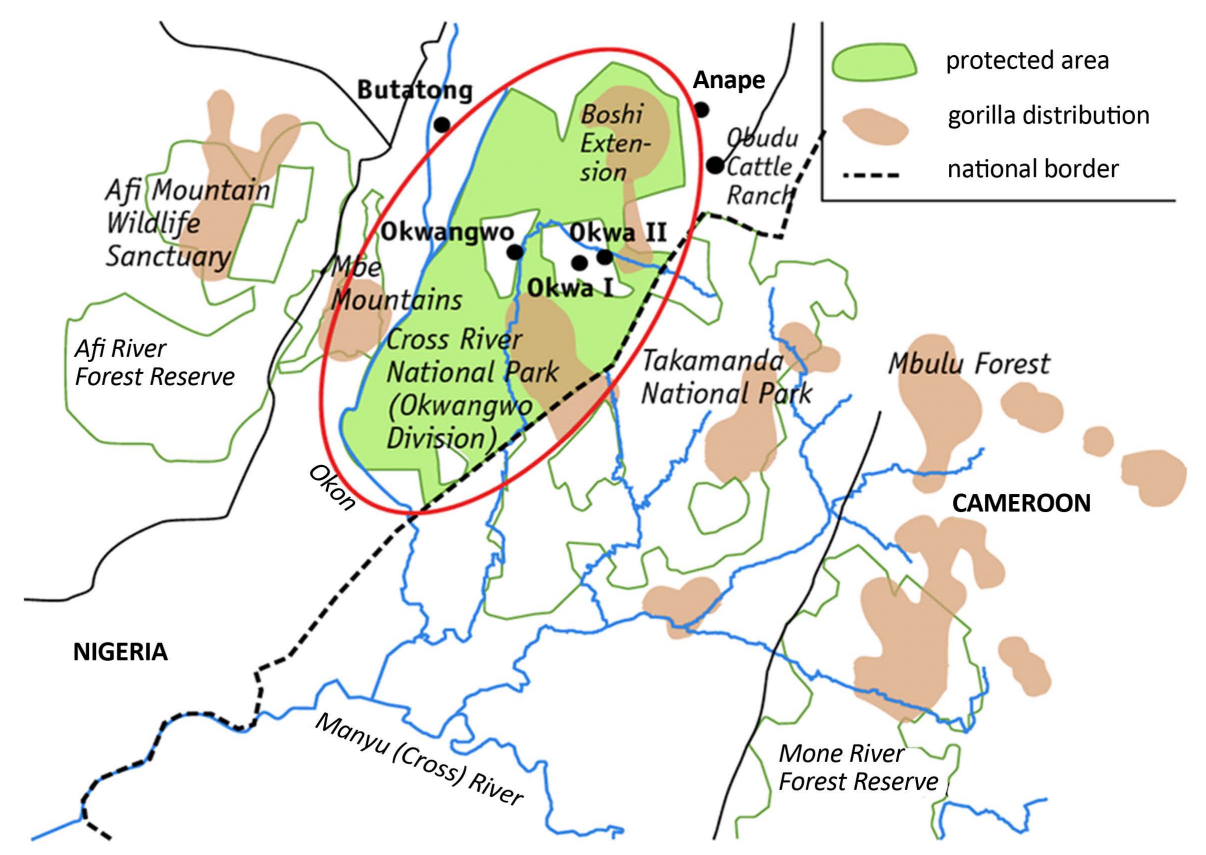

Figure 1. Map of the study area with Cross river state protected area in Okwangwo division and Gorilla distribution. Source: www.berggorilla.org, [17]. 
Table 1. Demographic information of hunters.

\begin{tabular}{|c|c|c|c|}
\hline VARIABLE & CATEGORY & FREQUENCY & PERCENTAGE \\
\hline \multirow{3}{*}{ MARITAL STATUS } & Single & 7 & 6.8 \\
\hline & Married & 96 & 93.2 \\
\hline & Total & 103 & 100.0 \\
\hline \multirow{5}{*}{ AGE } & $\leq 40$ & 59 & 57.3 \\
\hline & $41-60$ & 38 & 36.9 \\
\hline & $\geq 61$ & 6 & 5.8 \\
\hline & Total & 103 & 100.0 \\
\hline & Tertiary & 3 & 2.9 \\
\hline \multirow{6}{*}{$\begin{array}{l}\text { EDUCATIONAL } \\
\text { LEVEL }\end{array}$} & Secondary & 54 & 52.4 \\
\hline & Primary & 41 & 39.8 \\
\hline & No formal & 5 & 4.9 \\
\hline & Total & 103 & 100.0 \\
\hline & Holiday hunter & 3 & 2.9 \\
\hline & Full time hunters & 38 & 36.9 \\
\hline \multirow[t]{5}{*}{ TYPE OF HUNTER } & Occasional hunter & 60 & 58.3 \\
\hline & Social hunter & 2 & 1.9 \\
\hline & Total & 103 & 100.0 \\
\hline & $\leq 20,000$ & 28 & 27.2 \\
\hline & $20,001-40,000$ & 22 & 21.4 \\
\hline \multirow[t]{5}{*}{ INCOME } & $40,001-60,000$ & 22 & 21.4 \\
\hline & $>60,000$ & 31 & 30.1 \\
\hline & Total & 103 & 100.0 \\
\hline & $\leq 3$ & 10 & 9.7 \\
\hline & $4-6$ & 46 & 44.7 \\
\hline \multirow[t]{3}{*}{ HOUSEHOLD SIZE } & $7-9$ & 29 & 28.2 \\
\hline & $>9$ & 18 & 17.5 \\
\hline & Total & 103 & 100.0 \\
\hline
\end{tabular}

Source: Field Survey, 2015.

The result reveals that $27.2 \%$ (28) of the hunters interviewed earn N20,000 or less from hunting a month, 21.4\% (22) earn between N20,000 - N40,000 per month, 21.4\% (22) earn between N40,000 - N60,000 per month and $30.1 \%$ (31) earn more than N60,000 from hunting per month.

Table 2 shows the result of investigation of the different types of hunters and their monthly income. The result revealed that there is no significant different in the mean income among the hunter types [19].

Table 3 shows that Okwango division has the highest number of snares in all the period considered and next to it is Afi division while Mbe division has the least in the period considered. The distribution of number of gunshot heard in the three divisions for the period considered reveals that Afi division has the highest number of gunshot heard in 2011 and 2012 and Mbe division has the highest in 2013 and 2014 respectively. On the other hand, Mbe division has the least number of gunshot heard in 2011 and 2012 while Afi division and Okwango has the least in 2013 and 2014 respectively.

The result from Table 3 further shows that Mbe has the highest number of extended catridges throughout the stated period followed by Afi and Okwango division. The result further stated that Mbe has the highest number 
Table 2. Depicts the different types of hunter and their income range.

\begin{tabular}{cccccc}
\hline \multirow{2}{*}{ TYPES OF HUNTER } & \multicolumn{2}{c}{ INCOME } & \multicolumn{2}{c}{ TOTAL } \\
\cline { 2 - 6 } & $\leq 20,000$ & $20,001-40,000$ & $40,001-60,000$ & 0 & 3 \\
\hline HOLIDAY HUNTER & 0 & 0 & 3 & 7 & 16 \\
FULL TIME HUNTERS & 7 & 8 & 12 & 15 & 38 \\
OCCASIONAL HUNTER & 19 & 14 & 0 & 0 & 60 \\
SOCIAL HUNTER & 2 & 0 & & 2 \\
\hline
\end{tabular}

Source: Field Survey, 2015.

Table 3. Patrol data of poaching activities in Afi-Mbe and Okwango.

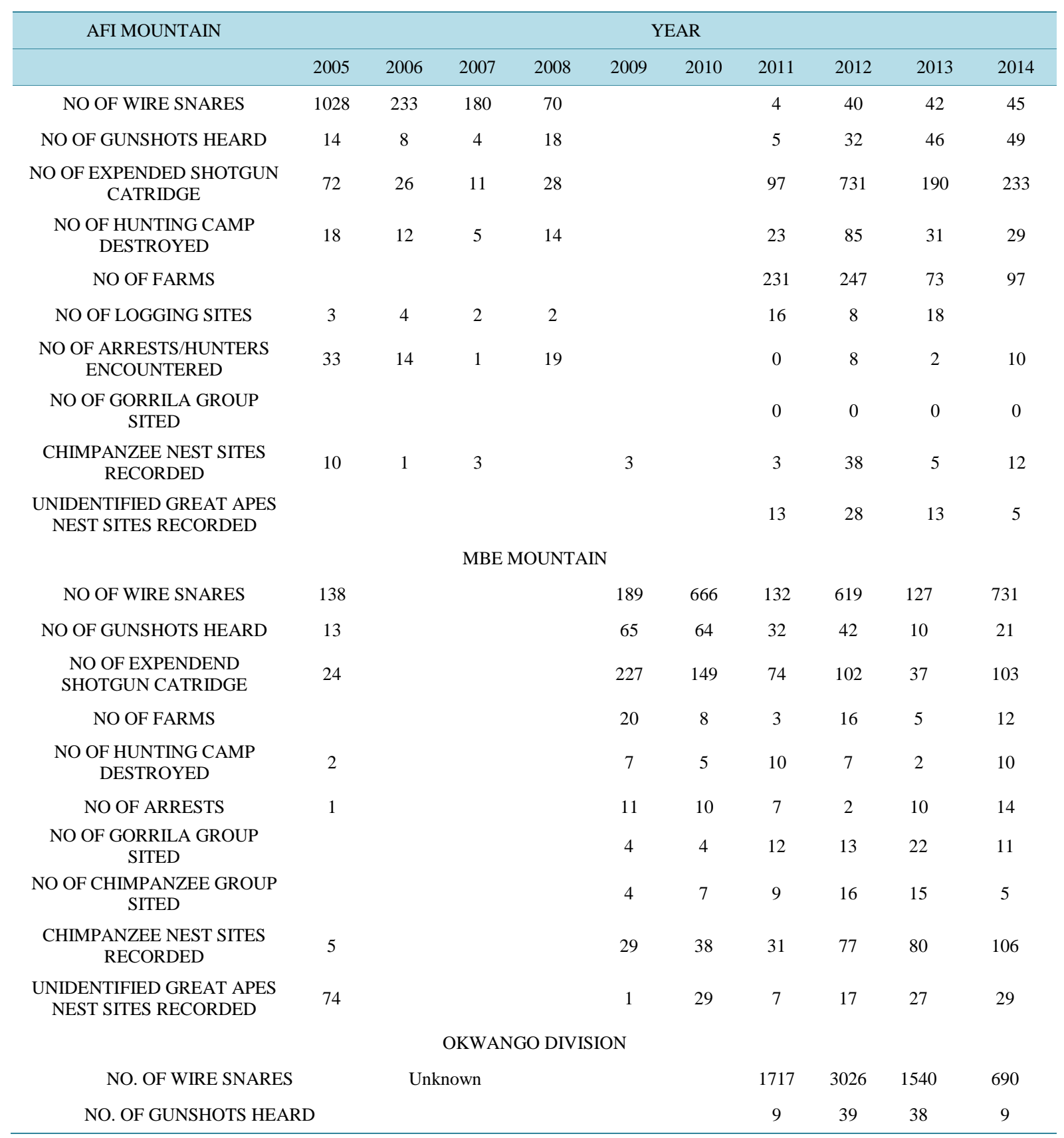




\begin{tabular}{|c|c|c|c|c|c|}
\hline \multicolumn{6}{|l|}{ Continued } \\
\hline NO. OF EXPENDED CARTRIDGES & & 309 & 1065 & 757 & 463 \\
\hline NO. OF HUNTING SHEDS DESTROYED & 7 & 59 & 130 & 106 & 80 \\
\hline NO. OF FARMS RECORDED & & 54 & 25 & 5 & 25 \\
\hline NO. OF LOGGING SITES & & 14 & 27 & 8 & 7 \\
\hline NO. OF POACHERS APPREHENDED & 1 & 0 & 4 & 13 & 3 \\
\hline NO. OF GORILLA GROUPS SIGHTED & & 0 & 2 & 0 & 0 \\
\hline NO. OF CHIMPANZEE GROUPS SIGHTED & & 0 & 3 & 1 & 3 \\
\hline GORILLA NEST SITES & 47 & 21 & 21 & 59 & 26 \\
\hline CHIMPANZEE NEST SITES & 9 & 10 & 7 & 11 & 20 \\
\hline UNIDENTIFIED GREAT APE NEST SITES & & 1 & 22 & 11 & 1 \\
\hline
\end{tabular}

Source: Adapted from NCF-WCS progress reports [20].

of hunters shed destroyed in the period of 2011 and 2012 followed by Okwango and Afi and in 2013, Okwango, Mbe and Afi has the highest respectively while in 2014, it is Mbe, Okwango and Afi. result on the number of hunters apprehended from the three division depicts that it is either decreasing or increasing at one period or the other from all the three division.

\section{Discussion}

Often times alternative livelihood project fail because of diverse reason, one of the major reasons is that most NGOs fail to look at the felt need of the target group, their level of operation and income from such operation especially when it has to do with hunting. Lack of adequate attention to the role of bushmeat as an important contributor to local livelihoods by development.

Agencies, non-governmental and inter-governmental organizations, and national governments contribute to the unsustainable hunting of bushmeat in tropical forests [21].

From the result, most of the hunters are married with children not less than three in which the majority falls within the range of 20 - 40 years with no other substantial means of income. This implies that the drivers of hunting are both income and protein to keep the family going (i.e. either for protein or income). Also considering the age bracket, it makes hunting activity more effective as they are still young and energetic. Also, majority are either school certificate or first leaving certificate holder which make them more dependent on hunting to survive.

Adding to this fact, even if they get other jobs, looking at their qualification, they are likely to get peanuts, thus hunting cannot be completely cut out rather it will be an additional means of income which corroborated Fa and Brown [1] It is however important that whatever alternative be provided must supersede the amount made from hunting either on a daily basis or on a monthly basis for it to be sustainable.

It was also observed that majority of the hunters do not have any idea of what other occupation they could do to solve the unending need for protein and income. In actual fact over $93 \%$ of them have no single idea other than hunting; the few who stated animal husbandry were given an option. This means that there is every possibility of any alternative provided to result to a failure as it seems hunting is part of the way of live of these people.

Todd [19] divided Poachers into three categories: Subsistence level, commercial level and syndicate level thus stating that all levels are equally critical. This study further divide the types of hunters into four types based on the time and reason why they hunt:

1) Holiday hunter

2) Occasional hunter

3) Fulltime/core hunter

4) Social hunter

HOLIDAY HUNTER: This involves students who on holidays go back to their villages to hunt for income. This style could be heavy hunting i.e. sleeping in the forest for days killing and drying the animal or it could be 
on a daily basis prior to the date of resumption depending on the need of the student. This type of hunter is very few, of all the hunters interviewed only $2.9 \%$ falls into this group.

OCCASIONAL HUNTER: These are hunters with no specific time for hunting; they can hunt whenever they need cash or protein. The times/days they spend in the forest hunting is dependent on the need per time. They can kill any species to meet ends meet. The difference between this group and fulltime hunters is that they have other means of income. This is the most common type of hunters (58.3\%). This corroborate with Wicander and Coad, [11] who stated that Local people are most likely to go hunting if agricultural incomes were low. It was also stated in CBD report [22] that many people do not depend on wildlife resources as a full-time source of food or income, but as a buffer to see them through times of hardship (e.g. unemployment, illness of relatives, crop failure), or to gain additional income for special needs (e.g. school fees, festivals, funerals).

FULLTIME/CORE HUNTER: These involve hunters (36.9\%) with no other means of income. This category of hunters can spend weeks in the forest using gun and snares over a wild range of land hunting [21]. They have hunters shed in the forest where they dry or roast their kill. They are also referred to as heavy hunters.

SOCIAL HUNTER: This type of hunters are very few (1.9\%), they involve individual who hunt for social purpose: not for the protein or income but for the experience and enjoyment.

\section{Conclusion}

In conclusion, the study centered on hunters in Afi-Mbe-Okwango axis of Cross River state Nigeria with the view of getting information on hunter's income, time for hunting and reason for hunting and also information on poaching activities from the three axis. The study shows that hunters are of different categories based on the time, income and their reason for hunting thus the hunters are classified into four groups: social hunter, occasional hunter, holiday hunter and fulltime/core hunter. Also, the secondary report which is on poaching activities from 2005 to 2014 gives an idea about the fact that despite the Nigerian laws on full protection to endangered species, large-scale farming encroachment and illegal hunting of bushmeat and life captured wildlife and the efforts of numerous NGOs, the poaching activities are on the high side. It is therefore paramount to have a better view and understanding of the target group (Poachers) for better alternative and implementation.

\section{Acknowledgements}

The Authors will like to acknowledge the following individuals and Organizations that assisted and gave permission for the carry out of this research work.

The Management of National Park Service Headquarter at Abuja and the Conservator General (Mr. Aruna Tanko Abubakar) for given us permission and approval of the proposal.

The Wildlife Conservation Society (WCS), for assisting the researchers to have access to some of their resource materials and field staff.

\section{References}

[1] Fa, J.E. and Brown, D. (2009) Impacts of Hunting on Mammals in African Tropical Moist Forests: A Review and Synthesis. Mammal Review, 39, 231-264. http://dx.doi.org/10.1111/j.1365-2907.2009.00149.x

[2] Milner-Gulland, E.J. and Bennett, E.L. (2003) Wild Meat: The Bigger Picture. Trends in Ecology and Evolution, 18, 351-357. http://dx.doi.org/10.1016/S0169-5347(03)00123-X

[3] Wilkie, D.S. and Carpenter, J.F. (1999) Bushmeat Hunting in Congo Basin: An Assessment of Impacts and Options for Mitigation. Biodiversity and Conservation, 8, 927-955. http://dx.doi.org/10.1023/A:1008877309871

[4] De Merode, E., Homewood, K. and Cowlishaw, G. (2003) Wild Resources and Livelihoods of Poor Households in Democratic Republic of Congo. Overseas Development Institute Wildlife Policy Briefing Series 1.

[5] Noss, A. (1999) Manejo de fauna comunitario en el Gran Chaco, Bolivia. In: Montenegro, O.L. and Bodmer, R.E., Eds., Manejo y conservaciónde fauna silvestre en América Latina, Instituto de Ecología, La Paz, 109-116.

[6] Nasi, R., Taber, A. and Van Vliet, N. (2011) Empty Forests, Empty Stomachs? Bushmeat and Livelihoods in the Congo and Amazon Basins. International Forestry Review, 13, 355-368.

[7] Wilkie, D.S, Bennett, E.L., Peres, C.A. and Cunningham, A.A. (2011) The Empty Forest Revisited. Annals of the New York Academy of Sciences, 1223, 120-128. http://dx.doi.org/10.1111/j.1749-6632.2010.05908.X

[8] Leverington, F., Lemos, C.K., Courrau, J., Pavese, H., Nolte, C., Marr, M., Coad, L., Burgess, N., Bomhard, B. and 
Hockings, M. (2010) Management Effectiveness Evaluation in Protected Areas-A Global Study. 2nd Edition, The University of Queensland Brisbane Australia.

[9] Harrison, R.D. (2011) Emptying the Forest: Hunting and the Extirpation of Wildlife from Tropical Nature Reserves. Bioscience, 61, 19-924. http://dx.doi.org/10.1525/bio.2011.61.11.11

[10] Abernethy, K., Coad, L., Taylor, G., Lee, M. and Maisels, F. (2013) The Extent and Ecological Consequences of Hunting in Central African Rainforests in the 21st Century. Philosophical Transactions of the Royal Society, B, 368. http://dx.doi.org/10.1098/rstb.2012.0303

[11] Wicander, S. and Lauren, C. (2014) Learning our Lessons: A Review of Alternative Livelihood Projects in Central Africa. ECI, University of Oxford. Gland, Switzerland: IUCN.

[12] WCS Regional Action Plan (2011).

[13] WCS Revised Regional Action Plan (2014-2019).

[14] Vira, B. and Kontoleon, A. (2010) Dependence of the Poor on Biodiversity: Which Poor, What Biodiversity? A State of Knowledge Review. International Institute for Environment and Development, London.

[15] Van Vliet, N. (2011) Livelihood Alternatives for the Unsustainable Use of Bushmeat: Report Prepared for the CBD Bushmeat Liaison Group.

[16] WCS Annual Reports (2015) www.wcsnigeria.org

[17] Map of the Study Area (2015) www.berggorilla.org

[18] Lund (2012) Lund Research Limited. http://dissertation.laerd.com/snowball-sampling.php

[19] Todd Kaplan (2011) The Who, What \& Why of Poaching. Wildlfie Campus Module \# 1 Component \# 1.

[20] NCF-WCF BIODIVERSITY RESEARCH PROGRAMME (2005) A Gorilla Reconnaissance Survey of Okwa Hills, Okwango Division, Cross River National Park and NCF-WCF BIODIVERSITY RESEARCH PROGRAMME Progress Report of 2005 on Gorilla Monitoring in the Mbe Mountains.

[21] Lameed, G.A., Omifolaji, J.K., Abere, A.S. and Ilori, S.O. (2015) Hunting Intensity on Wildlife Population in Oban Sector of Cross River National Park. Natural Resources, 6, 325-330. http://dx.doi.org/10.4236/nr.2015.64029

[22] Convention of Biological Diversity (2008) Conservation and Use of Wildlife-Based Resources: The Bushmeat Crisis. Secretariat of the Convention on Biological Diversity, Secretariat of the Convention on Biological Diversity. 